\title{
RESISTENSI RUANG PUBLIK DI TENGAH COVID-19 PERSPEKTIF ISLAM DAN KOMUNIKASI MULTIKULTURAL
}

\author{
Andri Kurniawan, Nibrasatul Yumna, Erna Tantri \\ Prodi KPI - Universitas Islam Negeri Mataram \\ andrikurniawan@uinmataram.ac.id
}

\begin{abstract}
The public sphere in the midst of the Covid-19 pandemic experienced significant dynamics, because public sphere which is a shared property space as an arena for sharing public opinion is limited, especially in the Islamic view which emphasizes avoiding the plague. Moving away from the Covid-19 outbreak means staying away from the crowd as a form of priority to avoid danger. This study aims to describe public space in different circumstances amid a pandemic in an Islamic and multicultural perspective. The research method used is literature study through indepth analysis in parsing the problem in accordance with the term of research. The results of the research showed that public space in the middle of the Covid-19 pandemic experienced a shift in function to become a virtual public sphere. The phenomenon of public sphere in Islamic view and multicultural communication is normatively direct and threatening during the pandemic because it risks inviting a crowd so that many virtual-based spaces become active and effective spaces as dimensions of public sphere in the Covid-19 pandemic era.
\end{abstract}

Keywords: Public Sphere, Islam, Multicultural Communication, Covid-19

24 Resistensi Ruang Publik ditangah Covid-19 


\begin{abstract}
Abstrak
Ruang publik di tengah pandemi Covid-19 mengalami dinamika yang signifikan, bagaimana tidak ruang publik yang menjadi ruang milik bersama sebagai arena sharing opini masyarakat menjadi serba terbatas terlebih dalam pandangan Islam yang menekankan untuk menghindari diri dari wabah. Menjauh dari wabah Covid-19 berarti menjauh pula dari kerumunan masyarakat sebagai bentuk prioritas untuk menghindari mudarat. Penelitian ini bertujuan untuk memaparkan ruang publik dalam keadaan yang berbeda di tengah pandemi dalam perspektif Islam dan multikultural. Metode penelitian yang digunakan adalah studi pustaka melalui indepth analisis dalam mengurai permasalah yang sesuai dengan tema. Hasil penelitian bahwa ruang public di tengah pandemi Covid-19 mengalami pergeseran fungsi menjadi ruang publik daring (virtual). Fenomena ruang publik dalam tilikan Islam dan komunikasi multikultural secara normatif bersifat direct dan bersifat mengancam selama pandemi karena bersiko mengundang kerumunan sehingga banyak ruang yang berbasis virtual menjadi ruang aktif dan efektif sebagai dimensi ruang publik di era pandemi Covid-19.
\end{abstract}

Keyword: Ruang Publik, Islam, Komunikasi Multikultural, Covid-19 


\section{PENDAHULUAN}

Ruang publik (public sphere) di Indonesi banyak kita temukan di tempat - tempat terbuka dan santai seperti taman, masjid, warung kopi maupun cafe. Ruang publik memiliki peran penting dalam kehidupan manusia sebagai ranah diskusi dan musyawarah. Kebermanfaatannya menjadikan ruang publik menjadi salah satu perhatian pemerintah dalam tata kota untuk membuat ruang terbuka hijau. Semakin banyak ruang publik, maka semakin banyak pula komunikasi sosial dilakukan tanpa mengedepankan kepentingan personal. Dengan kata lain, berkomunikasi murni untuk berbagi opini yang dimiliki masyarakat.

Komunikasi sebagai proses pertukaran pesan yang dilakukan oleh satu individu kepada individu lainnya melaului media tertentu baik secara langsung bertujuan untuk memberikan pemaknaan pada pesan tersebut yang menghasilkan feedback. Komunikasi perspektif Islam dapat dilakukan dengan siapapun untuk memberi manfaat dibalik pesan yang akan disampaikan. Komunikasi menjadi penting dalam upaya kontrol sosial untuk menjalani kehidupan bermasyarakat yang berkelanjutan.

Latar belakang budaya yang berbeda mengakibatkan adanya perbedaan system kepercayaan, nilai serta norma yang berlaku dalam masyarakat. Pada saat berlangsung nya komunikasi antar budaya komunikator dan komunikan berusaha menciptakan satu pemahaman yang sama tanpa menghilangkan budaya sendiri sehingga keefektifan dalam berkomunikasi tetap terjadi. Dampak negatif yang ditimbulkan komunikasi antarbudaya yang kurang efektif yaitu stereotip yang beranggapan bahwa budaya lain tidak baik itu hanya berdasarkan persepsi sendiri, etnosentrisme dan lain lain. ${ }^{1}$

\footnotetext{
${ }^{1}$ Komunikasi antarbudaya merupakan model komunikasi yang dioperasionalkan oleh William B. Gudykunst dan Young Yun Kim. Model ini menekankan pada komunikasi antara orang-orang yang berasal dari budaya yang berlainan, atau komunikasi dengan orang asing (stranger). Komunikasi antarbudaya pada dasarnya sesuai untuk komunikasi tatap muka, khususnya antara dua orang. Model komunikasi tersebut dapat
} 


\begin{abstract}
Komunikasi antarbudaya juga memiliki faktor yang menghambat terjadinya komunikasi yaitu hambatan dari sudut pandang yang berbeda yaitu dimana saat dua orang berkomunikasi namun memiliki sudut pandang yang berbeda maka akan menimbulkan sebuah perdebatan. Yang kedua yaitu faktor bahasa di mana saat berkomunikasi dengan kelompok lain atau budaya lain yang tentu memiliki bahasa daerah yang berbeda pada saat komunikasi berlangsung komunikan ini harus benar benar memperhatikan apa yang disampaikan agar menerima pesan dengan baik, akan tetapi apabila orang dari kelompok lain tersebut menggunakan bahasa daerah sendiri maka komunikan ini akan susah dalam memahami dan memberikan timbal balik secara langsung maka
\end{abstract}

mempresentasikan komunikasi antara siapa saja, karena pada dasarnya tidak ada dua orang yang mempunyai budaya, sosiobudaya dan psikobudaya yang persis sama. Mukti Ali, Komunikasi Antarbudaya dalam Tradisi Agama Jawa, (Yogyakarta: Pustaka Ilmu , 2016), hlm. 16. itu disebut hambatan komunikasi antar budaya. ${ }^{2}$

$$
\text { Islam dalam pandangan }
$$

komunikasi multikultural selalu mengedepankan komunikasi yang moderat tanpa ada dikotomi ras, suku dan agama. Dasar toleransi yang tinggi kemudian menjadikan Islam sebagai agama yang mampu berdialektika dengan berbagai budaya dan agama. Terlebih pada saat pandemic Covid-19 yang harus memperhatikan kondisi lawan bicara dan tradisi yang meliputinya dengan mudah disesuaikan terhadap berbagai bentuk dinamika sosial yang terjadi.

\section{Kegiatan}

komunikasi multikultural saat pandemi berjalan tidak seperti biasanya karena harus lebih mengedepankan untuk menghindari bahaya terinfeksi virus dibandingkan manfaat komunikasi. Tentu ini akan berpengaruh terhadap beberapa titik kumpul masyarakat yang dijadikan sebagai ruang publik.

\footnotetext{
2 Alvin Sanjaya, "Hambatan Komunikasi Atarbudaya Antara Staf Marketing Dengan Penghuni Berkewarnegaraan Australia dan Korea Selatan DI Apatemen X Surabaya", Jurnal E-Komunikasi Vol.1 No.3, (2013), hlm. 260-261.
} 
Ruang publik menjadi ruang milik bersama sebagai arena sharing opini masyarakat menjadi serba terbatas terlebih dalam pandangan Islam yang menekankan untuk menghindari diri wabah. Menjauh dari wabah Covid-19 berarti menjauh pula dari kerumunan masyarakat sebagai bentuk prioritas menghindari mudarat dari pada mendatangkan maslahat. Inilah kemudian yang menjadikan ruang publik penting untuk didiskusikan karena mengalami dinamika fungsi era pandemic Covid-19.

\section{LITERATURE REVIEW}

Sebagai perbandingnan dan mengukur kabsahan artikel ini, berikut beberapa artikel yang terkait dengan tulisan penelitian ini, penelitian pertama oleh Andreu Casero-Ripollés ${ }^{3}$ dengan penelitian "Impact of Covid-19 on the media system. Communicative and democratic consequences of news

${ }^{3}$ Andreu Casero-Ripollés dengan penelitian "Impact of Covid-19 on the media system. Communicative and democratic consequences of news consumption during the outbreak", El profesional de la información, Vol. 29 No. 2, (Mei, 2020), hlm. 1-11. consumption during the outbreak" menggambarkan bahwa Covid-19 membatasi media sosial dalam menginformasikan urusan publik dibalik kemampuan media yang dapat mengakses banyak berita termasuk melalui platform digital yang menjadi saluran utama dalam penyaluran berita palsu tentang pandemi. Persamaan penelitian ini adalah aktifnya ruang publik di tengah pandemi karena kebutuhan informasi melalui media antimainstream dan media sosial. Akan tetapi, peneliti lebih tidak hanya melihat ruang publik secara virtual dan elektronik juga dalam konteks konvensional dalam kehidupan multikultural secara direct.

Penelitian kedua oleh Jufri Alkatiri $^{4}$ berjudul "Ahmadiyah Qadian dalam Perspektif Komunikasi Antarbudaya: kajian Tentang Agama di Runag Publik". Studi kasus Alkatiri menganalisis perbedaan budaya memiliki implikasi terhadap

\footnotetext{
4 Jufri Alkatiri, "Ahmadiyah Qadian dalam Perspektif Komunikasi Antarbudaya: kajian Tentang Agama di Runag Publik", (Disertasi, Pascasarjana UIN Syarif Hidayatullah, Jakarta, 2014), hlm. 1-725.
} 
komunikasi antarbudaya seperti tidak hanya dalam kehidupan perbedaan pemahaman dan dalam berbangsa dan bernegara dalam memaknai agama Isla $>\mathrm{m}$ antara masyarakat pun perlu diupayakan Jemaat Ahmadiyah dengan umat agar selalu ada ruang publik bagi Isla $>\mathrm{m}$ arus utama, yang masyarakat multikultural. berpengaruh secara signifikan. Persamaan penelitian ini adalah Persamaan penelitian terdapat pada menagmbil locus analisis ruang kajian Islam dalam komunikasi publik dalam yang memiliki fungsi multicultural, mendeskripsikan Islam dalam bingkai-bingkai kehidupan masyarakat yang multikultural. Perbedaan yang kontras pada penelitian ini adalah tidak memfokuskan ruang publik sebagai kajian melainkan hanya variabel tambahan dalam menunjukkan keterangan tempat.

Penelitian ketiga oleh nomatif. Namun, perbedaannya peneliti lebih melihat secara eksplisit bentuk ruang publik saat pandemi dengan sistem daring yang lebih dominan karena keberadaan ruang publik secara konvensional dapat memancing kerumunan, peneliti pun lebih mengedepankan konsep Islam dalam mengkaji ruang publik dalam Hendrikus T. Gedeona ${ }^{5}$ dengan judul “peranan Ruang Publik Dalam kebermanfaatanmnya di era pandemic Covid-19.

Kehidupan Masyarakat Multi kultural" merupakan penelitian yang lebih mengedepankan fungsi ruang publik secara normatif melalui alur berfikir Jurgen Habermas yang dikemas dalam kerangka berfikir yang dinamis bahwa ruang publik

${ }^{5}$ Hendrikus T. Gedeona, "Peranan Ruang Publik Dalam Kehidupan Masyarakat Multikultural", Jurnal Ilmu Administrasi, Vol. 5 No. 1 (2018), hlm. 33-43.

Melalui berbagai literature review di atas menunjukkan urgensi penelitian ini dalam meninjau polarisasi ruang pulik di tengah masyarkat plural selama pandemic COvid-19. Dinamika sosial mempengaruhi keberfungsian ruang publik dibalik tuntutan masyarakat memegang protokol kesehatan dalam memutus mata rantai penyebaran coronavirus. Berbagai literatur 
menganalisis berbagai dimensi juga sebagai penguatan dan kehidupan manusia di tengah pengabsahan data-data penelitian pandemi dari yang bersifat eksak melalui literature review dalam sampai dengan kajian-kajian agama pengembangan kajian atau analisis menunjukkan pentingnya melindungi yang memiliki relevansi berdasarkan diri dari wabah yang berimplikasi substansi. Kemudian dilakukan pula terhadap transformasi ruang publik. teknik analisis data penelitian METODE PENELITIAN

Pendekatan penelitian ini menggunakan library research yaitu pendekatan dengan teknik pengumpulan data melalui sumberdengan teknik content analysis, analisis yang dapat menghasilkan luaran konklusi data.

\section{HASI DAN PEMBAHASAN}

sumber kepustakaan yang memiliki relevansi kajian penelitian dengan menggunakan indepth analysis sebagai telaah term penelitian. Jenis penelitian yang dilakukan dengan jenis antropologi sosial, telaah terhadap keberadaan ruang publik di tengah pandemic Covid-19 pada masyarakat Islam dan Multikultural.

Adapun teknik pengumpulan data yang digunakan pada penelitian ini dengan cara mengumpulkan bahan-bahan kepustakaan yang relevan terhadap tema penelitian atau yang disebut sebagai teknik literer. Teknik literer sangat menentukan dalam penelitian selain sebagai teknik pengumpulan data

ingin memaparkan beberapa konsep termasuk yang sesuai dengan kata kunci dalam penelitian ini. Seperti komunikasi antarbudaya (multikultural) yang merupakan salah satu bidang kajian dalam ilmu komunikasi. Teori komunikasi multikultural mempunyai daya tarik untuk dibahas pada konsep behaviorisme yang secara khusus menggenralisasi konsep komunikasi diantara komunikator dan komunikan yang bebrebda kebudayaan dan membahas pengaruh kebudayaan terhadap kegiatan 


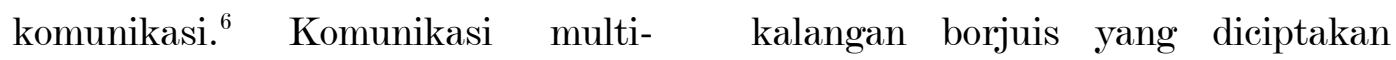
kultural dalam interpretasi yang seolah olah sebagai bentuk berbeda sebagai suatu proses penyikapan terhadap otoritas publik. ${ }^{7}$ komunikasi simbolik, interpretatif, transaksional, kontekstual yang dilakukan oleh sejumlah orang karena memiliki perbedaan derajat kepentingan tertentu, memberikan pengertian dan harapan secara berbeda terhadap apa yang disampaikan dalam bentuk perilaku tertentu sebagai makna yang dipertukarkan.

Dinamika komunikasi sosial dalam lingkup multikultural berporos pada kesepahaman anggota masyarakat. Kesepakatn bersama dapat dijalin di antaranya melalui pemanfaatan ruang publik dalam musyawarah sosial. Ruang publik dikenal juga dengan istilah public sphere yang ditulis pertama kali pada 1962 dalam bahasa jerman oeffentlichkeit oleh Jurgen Habermas. Ruang publik tersebut pada dasarnya merupakan ruang yang tercipta dari kumpulan orang orang tertentu dalam konteks sebagai

6 Lihat Hardiman,Budi F, Menuju Masyarakat Komunikatif, (Yogyakarta : Penerbit Khusus, 1993). hlm 72.

Jadi istilah ini dibentuk Habermas sebagai mediasi seluruh laipsan masyarakat dalam menjalin diskusi termasuk dalam mengatasi berbagai masalah atau isu yang sedang terjadi ditengah masyarakat.

Perkembangan Ruang Publik pada masa itu tidak luput dari adanya pertumbuhan literasi dan seni sastra yang kemudian berkembang menjadi sebuah perlawanan yang ada pada kenegaraan demi kemaslahatan yang merupakan permasalahan politik. Dengan hadirnya kedai-kedai kopi tersebut yang menajadi tempat perkempulan sehingga terciptanya jalan keluar dari isu-isu di negara tersebut dpat dipisahkan. Hal ini menunjukkan bahwa dibutuhkannya ruang untuk berkumpul, berawal sekedar tempat persinggahan berupa kedai-kedai kopi yang biasanya ditempati oleh penggiat sastra kemuudian menjadi tempat

7 Rulli Nasrullah, "Internet Dan Ruang Publik Virtual, Sebuah Refleksi atas Teori Ruang Publik Habermas", Jurnal Komunikator, Vol.4 No. 1 (2012) hlm. 35. 
perkumpulan bagi banyak ornag sehingga ditempat itulah tempat pemisah antara berbagai kelas-kelas sosial atau stratifikasi sosial tepecahkan, kemudian berubah menjadi tempatyang aman bagi mereka untuk mendiskusikan permaslahan kenegaraan Eropa yang absolut pada masa itu. Perkumpulan dari sekelompok orang yang berasal dari kelas sosial berbeda dengan mendiskusikan persoalan politik tentunya secara tidak langsung merupakan gambaran terjalinnya komunikasi antar budaya pada ruang publik dalam hal ini kedai-kedai kopi yang ada pada masa itu.

Habermas juga mengatakan kebebasan berbicara adalah syarat utama agar terjadi komunikasi umum dan diskursus tingkat tinggi walaupun mungkin itu sulit dilakukan $^{8}$. Kebebasan yang dimaksud apabila situasi dan kondisi yang mendukung untuk

\footnotetext{
8 Jannus Timbo Halomoan Siahaan, "Formasi Public Sphere Dalam Masyarakat Transisional (Studi Kasus Penyusunan Peraturan Daerah Nomor 3 Tahun 2007 Tentang Limbah Padat di Kabupaten Luwu Timur, Provinsi Sulawesi Selatan”, Jurnal Ilmu Pemerintah, Vol.3 No.2 (2017), hlm. 236 .
}

mengemukakan pendapat dan semua individu mendapat akses yang sama untuk berbicara. Saling berkumpul dan menyelesaikan persoalanpersoalan yang ada di dalam masyarakat. Dengan saaling berbagi ruang dan waktu untuk menyelesaikan isu tersebut.

Setelah memahami komunikasi dalam konteks multikultural dan konsep ruang publik kemudian menarik apabila dikaji pada kondisi saat ini. Keberadaan yang biasanya dapat dirasakan oleh semua kalangan masyarakat, namun setelah pandemi Covid-19 merebak di tanah air kemudian menjadikan ruang publik merubah konsep menjadi daring (online). Pandemi ini menjadi sebab berbagai dinamika di masyarakat seperti pola hidup dan interaksi sosial. Pandemi Koronoa pun menjadikan ruang publik secara normatif sebagai ruang hampa seperti taman bermain, warung kopi dan berbagai ruang terbuka karena mengharuskan masyarakat untuk stay at home dan menghindari kerumunan. 
Perlu kiranya kita lebih Coronavirus bersifat sensitif memahami pandemi Covid-19 atau yang sering disebut dengan Virus Corona. Selama 3 minggu terakhir, fokus utama epidemi baru penyakit coronavirus 2019 (COVID-19), beberapa tanpa asal dilacak, telah diidentifikasi dan cepat berkembang di Eropa, Amerika Utara, Asia, dan Timur Tengah, dengan kasus yang dikonfirmasi pertama kali diidentifikasi di Negara Afrika dan Amerika Latin. Pada 16 Maret 2020, jumlah kasus COVID-19 di luar Tiongkok meningkat secara drastis dan jumlah negara yang terkena dampak atau wilayah yang melaporkan infeksi ke WHO adalah $143 .{ }^{9}$

Wang berpendapat bahwa coronavirus merupakan virus RNA strain tunggal positif, berkapsul dan tidak bersegmen. Coronavirus tergolong ordo Nidovirales, keluarga keluarga Coronaviridae. Struktur coronavirus membentuk struktur seperti kubus dengan protein $\mathrm{S}$ berlokasi di permukaan virus.

9 Lihat Juliet Bedfort, dkk., "COVID-19: Towards Controlling of a Pandemic", The Lancet, Vol. 395, No. 10229, (March, 2020), hlm. 1015.

terhadap panas dan secara efektif dapat dinonaktifkan oleh desinfektan mengandung klorin, pelarut lipid dengan suhu $56^{\circ} \mathrm{C}$ selama 30 menit, eter, alcohol, asam prioksiasetat, detergen non- i onik, formalin, oxidizing agent dan kloroform. Klorheksidin tidak efektif dalam menonaktifkan virus. ${ }^{10}$

Kemudian, sudut-sudut ruang publik selama pandemi Covid-19 tidak lagi ramai seperti baiasanya karena kondisi wabah yang mengharuskan masyarakat merubah pola komunikasi dari ruang publik terbuka menjadi ruang publik daring menjadi dominan. Namun, setelah berbagai negara termasuk Indonesia telah menerapkan sitem new normal life ruang publik terlihat semakin hidup walaupun harus dengan memegang protokol Kesehatan yang telah ditetapkan.

Berikut salah satu contoh bentuk ruang publik pada masa pandemi dalam status new normal life.

10 Lihat Yuliana, "Corona virus disease (Covid -19); Sebuah Tinjauan Literatur", Wellness and Healthy Magazine, Vol. 2 No, 1 (Februari, 2020). Hlm, 188-189. 


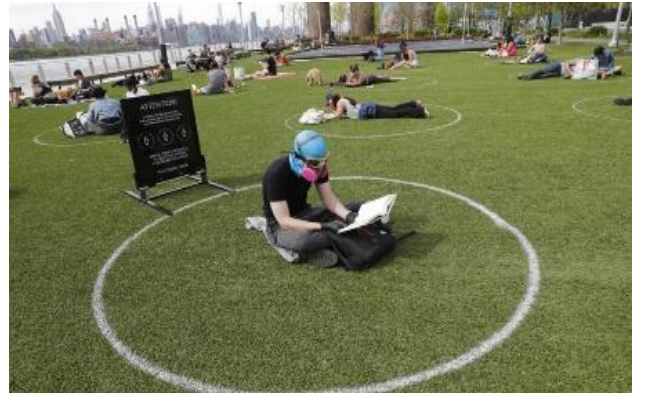

(Taman di Kota New York Dihiasi Lingkaran Jarak,.Ridley Goodside duduk di dalam lingkaran di Domino Park, New York, Senin (18/5). Ruang publik perlu didesain agar sesuai dengan kondisi masyarakat saat pandemi. Ilustrasi) ${ }^{11}$

$$
\text { Namun dewasa ini, }
$$

perkembangan tekhnologi Informasi dan Komunikasi tentunya menjadi salah satu mediasi dan sebagai ruang publik virtual dengan tidak langsung mempertemukan suatu kebudayaan dengan kebudayaan lainnya, seperti internet. Internet merupakan salah satu Wasilah ataupun media dari terjalinya Komunikasi Antarbudaya. Pengaruh internet sangatlah besar baik untuk kebutuhan pengguna pribadi maupun sebagai kontroling kebijakan-kebijakan pemerintah yang dapat memberikan ruang kepada masyarakat untuk menyuarakan kritikan, masukan ataupun dukungan terhadap kebijakan yang ada. Seperti maraknya penggunaan

11 Christiyaningsih, "Pandemi Covid-19 Beri Sudut Pandang Tata Kota Baru", dalam https://republika.co.id/berita/qbbwqa459/pan demi-covid19-beri-sudut-pandang-tata-kotabaru, diakses pada (22 Juni 2020). media sosial dalam hal ini aplikasi Twitter yang dapat menjadi ruang publik. Pengguna aplikasi twitter juga berasal dari beberapa kalangan, tidak hanya pengguna individu, media jurnalisme online tapi juga para pembisnis bahkan mayoritas digunakan oleh penggiat politik, prsiden dan penjabat dalam negeri.

Tingginya popularitas dan pengguna aktif Twitter menyebabkan layanan ini telah dimanfaatkan untuk berbagai keperluan dalam berbagai aspek, fasilitas yang disediakan juga cepat mendapat respon dari masyarakat aktif untuk bergerak bersama yang kemudian memilik peluang besar untuk ditindak lanjuti, karena ada ranting kicauan yang tentunya dapat dibaca dan dilihat oleh banyak orang. Pengguna aktif jelas berasal dari beberapa kemudayaan yang berbeda, namun tidak jarang memiliki satu tujuan dalam menyuarakan pendapat melalui ruang publik twitter sebagai sarana protes, kampanye politik, sarana pembelajaran, dan sebagai media komunikasi darurat. Dari narasi ini bahwa dapat dikatakan 
sebagai ruang publik karena perbincangan yang menyangkut kepentingan bersama tertuang secara terbuka di sana. ${ }^{12}$

Hubungan antara media dan masyarakat idealnya dapat dilihat sejajar, perlu ditekankan media juga merupakan refleksi dari hak untuk mengeluarkan pendapat, sedangkan masyarakat merupakan refleksi dari hak untuk memperoleh informasi. ${ }^{13}$ Adapun gagasan penekanan pada ruang publik sangat terbuka dan dapat diakses untuk semua menjadi pusat makna dari aturan publisitas, akses yang tersedia pun tidak membeda-bedakan kelas dan staratifikasi sosial dan tentunya hal ini menunjukkan bagaimana kesimbangaann dari masyrakat akktif yang berpartisipasi dalam diskusi publik dengan kesamaan sosial serta keberagaman budaya guna menjunjung tinggi nilai

12 Muhammad Sofyan Abdurrahman, "Twitter Dan Ruang Publik Pemerintahan Lokal Yang Partisipatif (Telaah atas Komunikasi Politik Ridwan Kamil Melalui Twitter)" Jurnal Penelitian Komunikasi dan Pembangunan, Vol.15 No. 2, (2014).

13 Ristiana Kadarsih, "Demokrassi dalam Ruang Publik", eJurnal Dakwah, Vol. IX No 1(Juni-2018). kebersamaan dan demi kebaikan bersama sebagaimana yang disebutkan habermas sebagai arena topik diskusi dibatasi pada kebaikan bersama.

Komunikasi antar budaya dalam tinjauan Public Sphere tentunya memiliki beragam keterkaitan yang tidak dapat dipisahkan dan memiliki andil satu sama lain. Melirik kepada perkembangan hadirnya ruang publik menurut Jurgen Habermas jelas sekali komunikasi antarbudaya hadir secara tidak langsung. Dalam satu ruang publik tertentu dihadiri oleh sekian banyak orang yang berasal dari kelompok yang berbeda, golongan yang berbeda, lapisan sosial yang berbeda, namun melebur menjadi satu dalam satu ruang publik melakukan interaksi dan komunikasi dalam menyelesaikan persoalan dan baik itu terkait isu-isu politk maupun prmasalahan lainnya yang menyangkut kemaslahatan bersama.

Perkembangan ruang publik tidak hanya terpaku pada perkumpulan sekelompok orang 
tertentu dalam ranah menempati satu ruang yang sama, bertukar pandang dan komunikasi secara langsung. Tapi ada satu wadah baru yang dapat menjadi ruang publik yaang menampung keberagamanan, baik itu budaya, ras,kelas sosial dan lain sebagainya. Yaitu adanya internet dan sejumlah aplikasi media sosial yang mefasilitasi. Seperti hadirnya Twitter, sejumlah persoalan ditampung di bincangkan oleh pengguna aktif yang tentunya memiliki peranana penting dan pengaruh besar untuk sampai kepada pemegang kebijakan. Dalam naungan ruang publik (media/ internet) tentunya bertemunya ada banyak sekali individu dan kelompok yang berasal dari keberagaman budaya tertentu berbaur berinteraksi saling mengemukakan pendapat, kritikan, untuk sama-sama menyuarakan dan menidaklanjuti persoalan yang tentunya sesuai harapan dan tujuan yang ingin dicapai.

Integritas dan solidaritas
masyarakat dalam penyelesaian
perkara yang menyangkut khalayak

\footnotetext{
${ }^{14}$ Adi Himawan, "Keterlibatan Warga dalam Pembentukan Ruang Publik (Analisa Pembentukan Ruang Publik dalam Revitalisasi Pasar Tradisional di Kota Surakarta)", Jurnal Analisa Sosiologi, Vol.2 No 1, (Oktober- 2013), hlm. 2-3
} 
menghadapu tirani kepentingan. Contoh masjid sebagai ruang publik adalah mencerminkan ruang netral dari berbagai kepentingan yang dapat memecah belah umat dan merusak tatanan kehidupan beragama, berbangsa dan bernegara. $^{15}$

Dalam tinjauan Islam melihat dinamika saat ini relevan dengan anjuran pemerintah dan agama untuk berperilaku hidup yang sehat, tetap diam di rumah atau beraktifitas dengan konsep new normal life sebagai ikhtiar untuk menghindari diri dari wabah yang sedang merebak di tanah air. Menghindari diri dari musibah, wabah atau marabahaya lebih diutamakan dari pada mengambil kebaikan (maslahat). Konsep ini begitu logis melihat angka positif terkena virus corona di Indonesia. Bagaimana tidak, bila konsep ini dibalik tentu bisa saja irrasional bahkan menunjukkan egoisme beragama dan bermasyarakat. Maksudnya, perilaku sederhana

${ }^{15}$ Andri Kurniawan, "Peran Masjid sebagai Sentra Dakwah Moderasi", Jurnal Komunikasi Islam, Vol. 10, No. 01, (Juni, 2020), hlm. 137. seperti mendekati perkumpulan dengan tujuan menjalin silaturahmi lebih diutamakan dari pada menghindar untuk beberapa waktu adalah bentuk kondisi beragama dan bermasyarakat dengan hawa nafsu.

Hal ini penting dalam membentuk perilaku kesehatan di tengah masyarakat plural. Posisi ruang publik konvensional pada kondisi new normal life menjadi lebih baik kembali kepada fungsinya sebagai ruang terbuka bagi masyarakat untuk bertukar ide dan gagasan dalam menyelesaikan masalah maupun membuat kesepakatan bersama dapat dimulai melalui ruang publik dengan memegang protokol kesehatan seperti menggunakan masker, duduk berjarak dan mencuci tangan setelah memegang benda yang bersifat umum menjadi buah komitmen untuk bersama memutus mata rantai penyebaran Covid-19.

Dengan demikian, kehidupan multikultural dan masyarakat Islam dalam mengisi ruang publik di tengah pandemi sudah semestinya mengedepankan toleransi dan 
kesadaran bersama untuk melawan virus corona yang masih mengalami mobilisasi dari orang ke orang dengan waktu yang cepat. Pasca pandemic diharapkan menjadi evaluasi pemerintah dan juga masyarakat untuk tetap mengkapanyekan pola hidup sehat untuk meningkatkan imunitas tubuh agar sulit terkena virus. Sehingga, new normal life menjadi Langkah awal recovery pasca pandemi untuk memulihkan sistem sosial bahkan pariwisata sebagai salah satu income terbesar untuk bangsa Indonesia.

\section{KESIMPULAN}

Ruang publik di tengah pandemi Covid-19 mengalami pergeseran fungsi dan mayoritas beralih ke konsep ruang publik daring (online). Fenomena ruang publik dalam pandangan Islam selama pandemi Covid-19 minimal dijauhi karena beresiko tinggi dalam penyebaran virus karena menjauhi diri dari wabah dan bahaya lebih diutamakan dalam Islam dari pada mengedepankan kebaikan pada situasi yang bersamaan. Keberadaan ruang publik dalam kehidupan multikultural secara normatif bersifat direct dan mengancam karena memiliki resiko besar dalam penyebaran virus pada kerumunan masyarakat sehingga banyak ruang yang berbasis virtual menjadi ruang aktif dan efektif sebagai dimensi ruang publik. Pada kondisi new normal life, ruang publik dalam pandangan Islam dan khidupan multikultural menjadi angin segar dalam menjalankan aktifitas sosial dan komunikasi sebagaimana biasanya dengan komitmen kolektif memegang protokol kesehatan dalam memutus mata rantai penyebaran Covid-19.

\section{DAFTAR PUSTAKA}

Adi Himawan, Keterlibatan Warga dalam Pembentukan Ruang Publik (Analisa Pembentukan Ruang Publik dalam Revitalisasi Pasar Tradisional di Kota Surakarta), Jurnal Analisa Sosiologi, Vol.2 No 1, Oktober- 2013.

Alvin Sanjaya, Hambatan Komunikasi Atarbudaya Antara Staf Marketing Dengan Penghuni Berkewarnegaraan Australia dan Korea Selatan DI Apatemen X Surabaya, Jurnal E-Komunikasi, Vol.1 No.3, 2013. 
Komunike, Volume XII, No. 1 Juni 2020

Andreu Casero-Ripollés, Impact of Covid-19 on the media system. Communicative and democratic consequences of news consumption during the outbreak, El profesional de la información, Vol. 29 No. 2, Mei 2020 .

https://doi.org/10.3145/epi.20 20.mar.23

Andri Kurniawan, Peran Masjid sebagai Sentra Dakwah Moderasi, Jurnal Komunikasi Islam, Vol. 10, No. 01, Juni2020.

https://doi.org/10.15642/jki.2 $\underline{020.10 .1 .125-145}$

Christiyaningsih, "Pandemi Covid-19 Beri Sudut Pandang Tata Kota Baru", dalam https://republika.co.id/berita/q bbwqa459/pandemi-covid19beri-sudut-pandang-tata-kota-

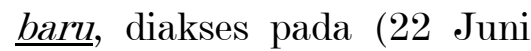
2020).

Hardiman,Budi $\quad$ F, Menuju Masyarakat Komunikatif, Yogyakarta : Penerbit Khusus, 1993.

Hendrikus T. Gedeona, Peranan Ruang Publik Dalam Kehidupan Masyarakat Multikultural, Jurnal Ilmu Administrasi, Vol. 5 No. 1, 2018.

Jannus Timbo Halomoan Siahaan, Formasi Public Sphere Dalam Masyarakat Transisional (Studi Kasus Penyusunan Peraturan Daerah Nomor 3 Tahun 2007 Tentang Limbah
Padat di Kabupaten Luwu Timur, Provinsi Sulawesi Selatan, Jurnal Ilmu Pemerintah, Vol.3 No.2, 2017.

Jufri Alkatiri, Ahmadiyah Qadian dalam Perspektif Komunikasi Antarbudaya: kajian Tentang Agama di Ruang Publik, Disertasi, Pascasarjana UIN Syarif Hidayatullah, Jakarta, 2014

Juliet Bedfort, dkk., "COVID-19: Towards Controlling of a Pandemic", The Lancet, Vol. 395, No. 10229, (March, 2020), hlm. 1015.

Juliet Bedfort, dkk., COVID-19: Towards Controlling of a Pandemic, The Lancet, Vol. 395, No. 10229, March2020 .

Muhammad Sofyan Abdurrahman, Twitter Dan Ruang Publik Pemerintahan Lokal Yang Partisipatif (Telaah atas Komunikasi Politik Ridwan Kamil Melalui Twitter), Jurnal Penelitian Komunikasi dan Pembangunan, Vol.15 No. 2, 2014. Ristiana Kadarsih, Demokrassi dalam Ruang Publik, eJurnal Dakwah, Vol. IX No 1, Juni2018.

Mukti Ali, Komunikasi Antarbudaya dalam Tradisi Agama Jawa, Yogyakarta: Pustaka Ilmu, 2016. 
Komunike, Volume XII, No. 1 Juni 2020

Rulli Nasrullah, Internet Dan

Yuliana, Corona virus disease (Covid Ruang Publik Virtual, Sebuah Refleksi atas Teori Ruang Publik Habermas, Jurnal Komunikator, Vol.4 No. 1, 2012.

-19); Sebuah Tinjauan Literatur, Wellness and Healthy Magazine, Vol. 2 No, 1,Februari-2020. 